\title{
Consumer Rights Today: Are They in Business or Out of Business?
}

\author{
Sami Alsmadi \\ Professor of Marketing, Faculty of Economics \& Administration \\ King Abdulaziz University, Jeddah, Saudi Arabia \\ E-mail: samis@yu.edu.jo
}

Ibrahim Alnawas (Corresponding author)

Marketing Department, AL-Zaytoonah Private University of Jordan, Amman, Jordan

E-mail: alnawas_s3s@hotmail.com

Received: September 24, $2011 \quad$ Accepted: December 6, $2011 \quad$ Published: February 1, 2012

doi:10.5539/ijms.v4n1p159 URL: http://dx.doi.org/10.5539/ijms.v4n1p159

\begin{abstract}
Research shows that, in the quest for profit, some producers and marketers are likely to pay little attention to basic consumer rights. Even their formal business strategies and policies in relation to consumer protection are not appropriately turned into actions in the marketplace.

This article looks at the marketing literature pertaining to corporate social responsibility and consumerism focusing on basic consumer rights, including the right to safety; the right to be informed; the right to choose and; the right to be heard. The analysis examines various intricacies involved in consumerism in the broad context of corporate social responsibility and ethical marketing behavior, highlighting areas where more attention is needed. The conclusion emphasizes a strong need to establish a universal standardized marketing practice with regard to consumerism in the marketplace.
\end{abstract}

Keywords: Consumer rights, Ethics, Social responsibility, Consumerism, Marketing behavior

\section{Introduction}

The literature reveals that tough competition for custom often gives rise to socially irresponsible business behavior by both producers and marketers that manifests itself in abusive and often dishonest marketing practice. Very often, many consumers are victimized as their basic rights are substantially threatened. Questionable selling practices, unfair price discrimination, deceptive advertising, inaccurate description of products, undisclosed product side-effects, seriously inferior products, unclear labeling, misleading packaging, false promises, and promoting harmful products are examples, among many, of much unethical marketing behavior (Pride and Ferrell, 2008). For example, research evidence showed that tobacco companies aggressively targeted smokers to prevent them from quitting, using attractive statements like 'Light' and 'Low tar' (Cataldo and Malone, 2008). Certainly, unfair marketing practice provokes action from different stakeholders in society, such as government agencies, special interest groups, and most importantly, consumerism activists. In fact, when marketing behavior deviates from acceptable standards in society, the exchange relationship between marketers and consumers is destroyed, resulting in consumer dissatisfaction, lack of trust in marketing, possible lawsuits, and overall public discontent.

In fact, protecting consumer rights, or the so-called consumerism- as part of corporate social responsibility, should be in the centre of every business strategy as it offers a marketing opportunity to enhance competitive advantages in the marketplace. This view emphasizes the interdependence between businesses and society and that both interact to shape an acceptable standard of business practice in modern economy. According to the systems approach, Davis et al (1980) viewed any business as a subsystem of an open system in a society, in which every business activity affects the society. In their Socio-economic model, Davis et al assume that every business in the system has both economic and social roles. Within this model, the real challenge of a business is to contribute to both roles. That is, a business is supposed to behave in such a way that it will be able to produce 
benefits for itself and, at the same time, for society. A balanced view is, therefore, required in which a business can make economic profits through a socially and, yet, ethically business behavior. The allegedly conflicting goals of profit maximization and social responsibility can then be reconciled.

The issue of consumerism and corporate social responsibility has received increased attention in the marketing literature, with more focus on the context of western countries. In the broader sense, however, it must be stressed that, as the world has become global village, and despite differences in market systems, business cultures, and levels of economic development, questions of consumer protection and corporate social responsibility are no longer western phenomenon, but rather a world-wide concern. Andresen (1977) believed that this trend was due to rising living standards, advances in mass media, increased traveling, improved technology and, increased consumer education across nations.

The aim of this article is to critically examine the marketing literature pertaining to corporate social responsibility and consumerism focusing on basic consumer rights, including the right to safety; the right to be informed; the right to choose and; the right to be heard. However, although such topic has received growing attention from practitioners and scholars ( For example, see Cox et al., 2004; Heinkel et al., 2001; Rivoli, 2003; Schepers and Sethi, 2003) knowledge in this area is still controversial (i.e. see May et al, 2007; Campbell, 2007). As there is no empirically grounded agreement about what is considered ethically acceptable behavior in the marketing discipline (i.e. see Caroll, 1983, 1991, 1998 and 2000; Brammer and Pavelin, 2006; Ellen, Webb, \& Mohr, 2006; Brammer and Millington, 2005), this paper comes to address various intricacies involved in consumerism in the broad context of corporate social responsibility, with particular reference to consumer rights, highlighting areas where more attention is needed.

On the contribution side, this paper contributes to the limited but growing body of knowledge, through providing a comprehensive review and systematic synthesis of the previous literature in the marketing discipline, focusing attention on the issue of consumerism. Drawing on both Western and Eastern perspectives, this paper would aid marketing decision makers to take more socially responsible view on consumer rights and also assist them in taking a balanced view between the consequent costs of CSR activities and consumer profitability.

\section{Corporate social responsibility (CSR)}

Corporate social responsibility can be defined as "an organization's obligation to maximize its positive impact and minimize its negative impact on society" (Pride and Ferrell, 2008), or any concept concerning how managers should handle public policy and social issues (Windsor, 2006). In the broader sense, corporate social responsibility implies that organizations are part of a larger society, thus accountable to that society for their actions (Kerin et al, 2009; Churchill and Peter, 1995). For example, a study showed that health has become a CSR strategy for the global food and beverage industry in the context of government concern to address increasing obesity rates (Herrick, 2009). Clearly, an organization is responsible to the whole society, including all stakeholders. Organization's investment in CSR is believed to create value not only for society but also for the organization itself. However, the term 'social responsibility' is not clear enough to different people in business (for example, Whang, 1999). Very often, this lack of clarity in understanding stems from relative disagreement on the nature and scope of social responsibility, given the diversity of values in different cultural contexts. Furthermore, ambiguity seems to surround ethical behavior of many businesses. Alsmadi explained that a marketing action may be judged as ethical by some stakeholders, and yet unethical by others. Even a clear unethical behavior may, sometimes, be inadvertently perpetrated. As ethics can, sometimes, be defined by the situation, good judgment is paramount. Therefore, ethical integrity in marketing conduct should always be essential in CSR for all businesses (Alsmadi, 2009). Pride and Ferrell (2008) highlighted three interrelated issues of CSR: First, Natural environment: it means taking care of the environment while doing business. For example, an organization may promote the 3Rs concept (Reuse, Recycle, and Reduce waste). Another way of showing concern for the environment is to embrace Green marketing strategy- environmentally friendly marketing approach (for more information, see Saha, and Darnton, 2005; Alsmadi, 2007); Second, Consumerism: it refers to all efforts made, at different levels, to protect consumer rights in the society, or "a social movement seeking to augment the rights and power of buyers in relation to sellers" (Kotler, 1972). The consumerism movement became a major force, originally in the U.S.A. and then in the rest of the world, from the 1960s onwards (Abratt and Sacks, 1988). Consumerism will be addressed in more details later in this article. Third, Community relations: it refers to business activities and communication efforts that seek to reinforce and enhance an organization's image in the society.

Related to the above three issues, Pride and Ferrell viewed CSR as falling into four dimensions (or four broad responsibilities): 
1) Economic responsibility: basically, all companies have an economic responsibility to make economic profits that enable them to provide a decent return on investment to their owners and investors, offer quality products to consumers and, create jobs for the economy.

2) Legal responsibility: businesses are expected to respect and adhere to all business laws and regulations.

3) Ethical responsibility: businesses must behave according to an established professional code of ethicsacceptable business behavior as determined by various stakeholders and the organization itself. A close look at ethical marketing conduct will be taken later in this article.

4) Philanthropic responsibility: businesses can go beyond marketing ethics by linking their products (or revenues) to a particular social cause, a practice usually called cause-related marketing. That is, linking a charitable contribution of a company to its revenues. For example, a company may link fund raising for breast cancer to its product sales (i.e. donating $5 \%$ of its profits to this public concern). In addition to profits, philanthropic behavior can promote human welfare in society as do other dimensions of CSR. However, philanthropy is not necessarily required of an organization.

In a more focused view of CSR, Kerin et al (2009) outlined a framework of three related responsibilities of CSR:

1) Profit responsibility: profit responsibility means that an organization has an obligation to maximize benefits for its owners and shareholders. At the most basic level, all organizations have an economic responsibility to make healthy profits so that they can provide a decent return on investment to their owners and investors, create jobs for the society and, offer satisfactory products to the market. But, this view implies that an organization can address its economic responsibility as long as it stays within the rules of the game, which is engaging in an honest competition without deception and fraud.

2) Stakeholder responsibility: stakeholder responsibility stresses an organization's obligation to stakeholder groups who can affect its goal achievement. Ignoring stakeholders' demands for socially responsible marketing can destroy customers' trust and evoke government action. An organization that considers the diverse perspectives of stakeholders and addresses their needs in its business operations is said to have a "Stakeholder orientation" (Pride and Ferrell, 2008). Today, most organizations are under pressure to undertake initiatives that demonstrate a balanced perspective on stakeholder interests.

3) Societal responsibility: societal responsibility refers organization's commitment to both preservation of ecological environment (i.e. Green marketing orientation) and public welfare. Concerns about these aspects are expressed by various pressure and advocacy groups in society. A recent global initiative for Green marketing is the ISO 14000, which was undertaken by the International Standards Organization (ISO) in Geneva, Switzerland. The ISO 14000 is an international standard for environmental quality and green marketing practice. The ISO 14000 has been adopted by 157 countries (including USA, EU, and many Pacific Rim countries). Over 12500 companies around the world have met the ISO 14000, of which $21 \%$ are Japanese, putting Japan on top of the list (ISO survey, 2005). Societal responsibility that addresses public welfare can manifest itself in cause-related marketing, as explained earlier.

Today, it seems that survival and sustainable success of businesses are closely tied to adherence to high standards of social responsibility. Kotler and Keller (2006) concluded that, in the age of communication and digital economy, companies which did not behave ethically were at a great risk of being exposed. In the past, a disappointed customer used to spread a bad word-of-mouth about a company to few other people. Today, he/she can reach thousands, if not millions, of people through the internet. Indeed, thanks to technology that drives businesses closer to socially responsible behavior. From a strategic point of view, Porter and Kramer (2006) offered four justifications for CSR, including: moral obligation; sustainability; license to operate and; reputation. Based on these justifications, Porter and Kramer asserted that a company's competitive Advantage is directly linked to CSR. They continued "... the more closely tied a social issue is to a company's business, the greater the opportunity to leverage the firm's resources- and benefit society". A research evidence indicated that a business can be profitable and, yet socially responsible by adopting societal marketing concept (Abratt and Sacks, 1988).

\section{Ethical marketing behavior and consumerism}

A comprehensive framework by Kerin et al (2009) identified three main influences that affect ethical marketing behavior. They include:

1) Societal culture and norms: societal culture, which serves as a socializing force, determines what is right or wrong for people within a particular society. It sets a moral standard that reflects social as well as economic behavior. It also dictates societal values, norms, attitudes and, ethical behavior of individuals, groups, including business organizations. Needless to say, a particular business behavior that is judged as ethical in one culture 
may be viewed as an unethical in another culture. In that, societal culture provides an umbrella under which marketing behavior is viewed as ethical or otherwise.

2) Business culture and industry practice: as highlighted above, a societal culture establishes a foundation to understand moral business behavior. Business culture can be defined as "the effective rules of the game, the boundaries between competitive and unethical behavior, [and] the codes of conduct in business dealings" (Terpstra and David, 1991). Business culture dictates ethical behavior in several areas of business operations, of which the most important is the marketing exchange behavior between sellers and buyers, or the so-called ethics of exchange. The exchange process is eloquently explained in the consumer 'bill of rights', which was first outlined by President John Kennedy in 1962. Up to this date, the bill has been considered the basic foundation of consumerism movement. The bill includes four basic consumer rights:

i) The right to safety: it involves a consumer right to buy safe products. Most countries address this right by specifying safety standards for all products sold to consumers. From a legal point of view, even the illicit nature of a transaction should not deny consumers the right to safety and redress (Borna, 1989). Today, many harmful products are licensed for sale in most markets around the world (i.e. tobacco, alcohol products, junk food, sugary snacks, and seriously inferior quality goods). A harmful product is any product that is viewed as unsafe or unfit for its intended use (Jones and Middleton, 2007). Harmfulness may go beyond personal harm to others' harm (i.e. alcohols, firearms, gambling, pornography ... etc). Very often, hostility for unsafe products is evidenced by organized opposition of social, religious, political, and regulatory groups. For example, the public concern for consumer safety pushed a study to require plain packaging for tobacco products as a means to ban all tobacco promotions (Freeman et al, 2008). Nevertheless, these socially unacceptable products, though strictly regulated, are generally legal and desired by certain consumers. Undoubtedly, however, selling these harmful products is considered a breach of the consumer "right to safety".

ii) The right to be informed: this right implies that sellers must have an obligation to provide buyers with complete, credible, and accurate knowledge about products. Unfortunately, this right is not completely observed by many sellers. Very often, marketers are likely to disclose only positive information that is in favor of their products and neglect unfavorable information. Price, for example, is revealed only when it is a favorable factor in a product purchase, while product side-effects are not always indicated to consumers. Even if they are, they sometimes appear in unclear terms, in the hope of being disregarded by consumers. A study of direct-to-consumer advertising of prescription drugs found that the level of believable information on prescription drug risks and side effects was only (31\%), with yet lower level of believability (28\%) on prescription drug benefits (Beltramini, 2006). In the same context, a study highlighted a need for more information about new medical services in direct-to-consumer advertising of prescription drugs (Donohue, 2006). Some marketers go to an extreme when they exaggerate favorable product aspects in the hope of attracting buyers' attention. Clearly, the consumer 'right to be informed' is not completely observed by many marketers, which means another collision with consumerism.

iii) The right to choose: it is noticeable that marketers stock only profitable products, with priority being given to high margin items. If an item is not attractive enough to a retailer, he/she would not care to stock it. In that, what seems to be a good choice for a consumer may not be profitable enough to a marketer, thus a choice gap may exist. Evidently, this limits alternative choices to consumers, forcing them to select a big ticket item. Furthermore, many retailers require a special fee from manufacturers to stock a new product- a practice known as a 'slotting allowance' that exists in many retail industries (Bloom et al, 2001). On the one hand, this practice increases selling price for new products. On the other hand, it discourages the process of new product development. Overall, this practice further limits consumer choices. Obviously, consumerism suffers with regard to the consumer 'right to choose'.

iv) The right to be heard: this right is to ensure that consumer interests and concerns receive full consideration by policy makers. It also seeks to ensure that all types of consumer grievances are fairly and properly treated by marketers. Consumer grievances are often viewed as an opportunity for marketers to address weaknesses in their business operations. The 'right to be heard' is likely to be more observed in the western context than in the eastern context.

3) Corporate culture and expectations: the third factor that influences ethical marketing behavior is corporate culture, which involves values, ideas, thoughts and, attitudes shared by members of an organization (for example, see Grant, 2008). This culture is also influenced by expectations for ethical behavior as prescribed in an organization's code of ethics and practiced by co-workers and top managers. A code of ethics is a formal statement of ethical rules of behavior in certain situations (for example, see Zikmund, 2003). In theory, a 
marketing behavior of an organization must be guided by a particular code of marketing ethics, adopted by that organization. This code of ethics is also expected to be consistent with the universal code of marketing ethics adopted by the American Marketing Association (www. marketingpower.com). Below is the AMA code of marketing ethics that, theoretically, guides marketing conduct in the world:

\section{American marketing association statement of ethics}

\subsection{Ethical norms and values for marketers}

\section{Preamble}

The American Marketing Association commits itself to promoting the highest standard of professional ethical norms and values for its members. Norms are established standards of conduct expected and maintained by society and/or professional organizations. Values represent the collective conception of what people find desirable, important and morally proper. Values serve as the criteria for evaluating the actions of others. Marketing practitioners must recognize that they serve not only their enterprises but also act as stewards of society in creating facilitating and executing the efficient and effective transactions that are part of the greater economy. In this role, marketers should embrace the highest ethical norms of practicing professionals as well as the ethical values implied by their responsibility toward stakeholders (e.g., customers, employees, investors, channel members, regulators and the host community).

\subsubsection{General norms}

1) Marketers must first do no harm. This means doing work for which they are appropriately trained or experienced so that they can actively add value to their organizations and customers. It also means adhering to all applicable laws and regulations as well as embodying high ethical standards in the choices they make.

2) Marketers must foster trust in the marketing system. This means that products are appropriate for their intended and promoted uses. It requires that marketing communications about goods and services are not intentionally deceptive or misleading. It suggests building relationships that provide for the equitable adjustment and/or redress of customer grievances. It implies striving for good faith and fair dealing so as to contribute toward the efficacy of the exchange process.

3) Marketers should embrace, communicate and practice the fundamental ethical values that will improve consumer confidence in the integrity of the marketing exchange system. These basic values are intentionally aspirational and include: Honesty, Responsibility, Fairness, Respect, Openness and Citizenship.

\subsubsection{Ethical values}

Honesty-this means being truthful and forthright in our dealings with customers and stakeholders.

We will tell the truth in all situations and at all times.

We will offer products of value that do what we claim in our communications

We will stand behind our products if they fail to deliver their claimed benefits

We will honor our explicit and implicit commitments and promises.

Responsibility-this involves accepting the consequences of our marketing decisions and strategies.

We will make strenuous efforts to serve the needs of our customers.

We will avoid using coercion with all stakeholders.

We will acknowledge the social obligations to stakeholders that come with increased marketing and economic power

We will recognize our special commitments to economically vulnerable segments of the market such as children, the elderly and others who may be substantially disadvantaged.

Fairness-this has to do with justly trying to balance the needs of the buyer with the interests of the seller.

We will clearly represent our products in selling, advertising and other forms of communication; this includes the avoidance of false, misleading and deceptive promotion.

We will reject manipulations and sales tactics that harm customer trust.

We will not engage in price fixing, predatory pricing, price gouging or "bait and switch" tactics.

We will not knowingly participate in material conflicts of interest.

Respect-this addresses the basic human dignity of all stakeholders. 
We will value individual differences even as we avoid customer stereotyping or depicting demographic groups (e.g., gender, race, sexual) in a negative or dehumanizing way in our promotions.

We will listen to the needs of our customers and make all reasonable efforts to monitor and improve their satisfaction on an on-going basis

We will make a special effort to understand suppliers, intermediaries and distributors from other cultures.

We will appropriately acknowledge the contributions of others, such as consultants, employees and co-workers, to our marketing endeavors.

Openness-this focuses on crating transparency in our marketing operations.

We will strive to communicate clearly with all our constituencies.

We will accept constructive criticism from our customers and other stakeholders.

We will explain significant product or service risks, component substitutions or other foreseeable eventualities affecting the customer or their perception of the purchase decision.

We will fully disclose list prices and terms of financing as well as available price deals and adjustments.

Citizenship-this involves a strategic focus on fulfilling the economic, legal, philanthropic and societal responsibilities that serve stakeholders.

We will strive to protect the natural environment in the execution of marketing campaigns.

We will give back to the community through volunteerism and charitable donations.

We will work to contribute to the overall betterment of marketing and its reputation.

We will encourage supply chain members to ensure that trade is fair for or all participants, including producers in developing countries.

\section{Implementation}

Finally, we recognize that every industry sector and marketing sup-discipline (e.g., research, e-commerce, direct selling, direct marketing, advertising, etc.) has its own specific ethical issues that require policies and commentary. An array of such codes can be accessed via links on the AMA website We encourage all such groups to develop and/or refine their industry and discipline-specific codes of ethics in order to supplement these general norms and values.

\section{Conclusions and implications}

As outlined in the AMA code of marketing ethics, the consumer 'bill of rights' is addressed in a way that leaves no doubt in the minds of marketing decision makers regarding socially accepted marketing ethics. Despite the AMA emphasis on the spirit of consumerism, however, an ethical code of marketing conduct is rarely enough to ensure that consumer rights are always protected. Very often, lack of specificity in codified ethical marketing behavior is one reason behind violation of established consumer rights. Good personal judgment in different marketing situations is, therefore, paramount. As a matter of fact, ethical choices depend on personal moral philosophy of marketers. In this vein, two philosophies can be identified: Moral idealism and Utilitarianism (Kerin, 2009). Moral idealism views individual rights as universal in principle, irrespective of the outcome. This moral philosophy goes along with the consumer 'bill of rights', and appears to receive full support by consumer activists. On the contrary, Utilitarianism depends on the principle of 'the greatest good for the greatest number" by looking at the costs and benefits of a certain action. If benefits exceed costs, then it is considered ethical, while if not, the action is unethical. According to the Utilitarian moral philosophy, for example, if only few people will experience serious side-effects of a new product, while the majority will not, then the product is considered ethical, and thus can be launched. Meanwhile, the Moral idealism philosophy considers this product as unethical, and thus should not be sold in the market. Nestlé vice president, for example, defended a similar position by saying "... I don't understand why our product should work in 100 percent of cases" (Freedman, 1989).

Apparently, even in the most democratic western context, the opportunity for abusive and dishonest marketing behavior is still present as consumer rights continue to be threatened in several ways. Very often, consumer rights are more talked about in media stories than actually practiced in the market. In the Eastern context, in particular, marketing ethics are much worse. Research surveys show very little evidence to support strong respect for the consumer 'bill of rights'. In Turkey, for example, a study found that consumers faced difficulties with the products they purchased due to insufficient information about product use and care (Kaynak et al, 1992). 
In Jordan, one study revealed that consumers were likely to recognize a high level of unethical marketing behavior (Alsmadi and Al-Zobi, 2005). Another study found that the majority of Jordanian consumers shared a belief that marketing communications were generally lacking honesty and credibility, and that consumers were misled in variety of ways. The same study pointed out that most companies were favoring quick revenues over healthy long-term relationships with consumers (Alsmadi, 2004). Clearly, such findings were likely to further enhance the illusive image of consumerism.

In practice, marketing behavior is subject to a variety of rules and regulations, depending on the location where marketing is practiced. In that, each country has its own rules that apply to marketing conduct, thus generalization may not be possible. Yet, this raises a need to standardize marketing practice around the world. As indicated earlier, the AMA code of marketing ethics has the potential to provide a foundation upon which a universal standardized marketing practice can be established.

In fact, it is the ever presence of the consumer 'bill of rights' that makes a universal code of ethics an imperative CSR strategy for marketers. It is true that the consumerism movement has changed the face of business, but more work is still needed. Today, modern marketing practice must rise to address new ethical challenges and opportunities. In the drive for marketing excellence, different rules must emerge to deal with new realities. Socially acceptable marketing ethics always come with hard work.

Future research may address exact realities of consumerism and current marketing practice in particular countries, employing empirical investigation. Comparison with the AMA code of marketing ethics may also be incorporated in such investigation, along with analysis of each major aspect of ethical marketing behavior.

\section{References}

Abratt, R., and Sacks, D. (1988). The Marketing Challenge: Towards Being Profitable and Socially Responsible. Journal of Business Ethics, Issue 7, PP. 497-507.

Alsmadi, S. (2010). Marketing Research and Social responsibility: Ethical Obligations toward the society. Journal of Accounting, Business, and Management.

Alsmadi, Sami (2004). Consumer Attitudes Towards Ethics Of Television Advertising: An empirical Study of from the Perspective of Jordanian Consumer in the City of Zarqa. Journal of Al-Manarah, Vol. 10, No. 2, 243-268.

Alsmadi, Sami (2007). Green Marketing and the Concern over the Environment: An Empirical Study to Measure Environmental Consciousness of Jordanian Consumers. Journal of Promotional Management, Volume 13, No. 3-4, PP. 339-361.

Alsmadi, Sami and Al-Zobi, M. (2005). Consumer attitudes towards marketing deception: an empirical study of consumer behavior in the city of Irbid. Journal of Abhath Al-Yarmouk, Vol. 21, No. 2, 293-320.

Andresen, A. R. (1977). Consumerism Dissatisfaction as a Measure of Market Performance. Journal of Consumer Policy, (4), 311-322. http://dx.doi.org/10.1007/BF02179632

Beltramini, R. F. (2006). Consumer Believability of Information in Direct-to-Consumer (DTC) Advertising of Prescription Drugs. Journal of Business Ethics, Issue 63, PP. 333-343.

Bloom, P. N., Gundlach, G. T., Cannon, J. P. (2000). Slotting Allowances and Fees: Schools of Thoughts and Views of Practicing Managers. Journal of Marketing, April, PP. 92-109.

Borna, S. (1989). Illegal products and the Question of Consumer Redress. Journal of Business Ethics, Issue 8, PP.499-505.

Brammer, S., \& Millington, A. (2005). Corporate reputation and philanthropy: An empirical analysis. Journal of Business Ethics, 61, 29-44. http://dx.doi.org/10.1007/s10551-005-7443-4

Brammer, S., \& Pavelin, S. (2006). Corporate reputation and social performance: The importance of fit. Journal of Management Studies, 43(3), 435-456. http://dx.doi.org/10.1111/j.1467-6486.2006.00597.x

Campbell, J.L. (2007). Why would corporations behave in socially responsible ways? An institutional theory of corporate social responsibility. The Academy of Management Review, 32(3), 946-967. http://dx.doi.org/10.5465/AMR.2007.25275684

Carroll, A. B. (1999). Corporate social responsibility. Business and Society, 38(3), 268-296. http://dx.doi.org/10.1177/000765039903800303

Carroll, A.B. (1991). The pyramid of corporate social responsibility: toward the moral management of 
organizational stakeholders. Business Horizons, 34, 39-48. http://dx.doi.org/10.1016/0007-6813(91)90005-G

Carroll, A.B. (1998). The four faces of corporate citizenship. Business and Society Review, 100(1), 1-7. http://dx.doi.org/10.1111/0045-3609.00008

Carroll, A.B. (2000). Ethical challenges for business in the new millennium: Corporate social responsibility and models of management morality. Business Ethics Quarterly, 10(1), 33-42. http://dx.doi.org/10.2307/3857692

Cataldo, J. K., and Malone, R.E. (2008). False Promises: The Tobacco Industry, "Low Tar" Cigarettes, and Older Smokers. Journal of American Geriatrics Society, Vol. 56, 1716-1723. http://dx.doi.org/10.1111/j.1532-5415.2008.01850.x

Churchill, G. A., and Peter, J. P. (1995). Marketing: Creating Value for Customers. Irwin, Illinois, Chapter 3.

Cox, P., S. Brammer and A. Millington (2004). An Empirical examination of Institutional Investor Preferences for Corporate Social Performance. Journal of Business Ethics, 52(1), 27-43. http://dx.doi.org/10.1023/B:BUSI.0000033105.77051.9d

Davis, K., Frederick, W. C., and Blomstrom, R. L. (1980). Business and Society. New York, NY, McGraw-Hill.

Donohue, J. (2006). A History of Drug Advertising: The Evolving Roles of Consumers and Consumer Protection. The Milbank Quarterly, Vol. 84, No. 4, PP. 659-699.

Ellen, P. S., Webb, D. J., \& Mohr, L. A. (2006). Building corporate associations: Consumer attributions for corporate socially responsible programs. Academy of Marketing Science Journal, 34(2), 147-157. http://dx.doi.org/10.1177/0092070305284976

Freedman, A. M. (1989). Bad Reaction: Nestlé's Bid to Crash Baby- Formula Market in U.S. Stirs a Row. The Wall Street Journal, February 16, PP. A1-A16.

Freeman, B., Chapman, S., and Rimmer, M. (2008). The case for the Plain Packaging of Tobacco Products. Addiction, Vol. 103, Issue 4, PP. 580-590.

Grant, R. M. (2008). Contemporary Strategy Analysis (sixth edition). Oxford-UK: Blackwell Publishing Ltd., p. $134,178$.

Heinkel, R., A. Kraus and J. Zechner (2001). The Effect of Green Investment on Corporate Behaviour. Journal of Financial and Quantitative Analysis, 36(4), 431-449. http://dx.doi.org/10.2307/2676219

Herrick, C. (2009). Shifting Blame/ Selling Health: Corporate Social Responsibility in the Age of Obesity. Sociology of Health \& Illness, Vol. 31, Issue 1, PP. 51-65.

ISO survey (2005). Cited in Kerin et al (2009).

Jones, J. L., and Middleton, K. L. (2007). Ethical Decision-Making by Consumers: The Roles of Product Harm and Consumer Vulnerability. Journal of Business Ethics, PP 247-264.

Kaynak, E., Kucukemiroglu, O., and Odabasi, Y. (1992). Consumer Complaint Handling in an Advanced Developing Economy: An Empirical Investigation. Journal of Business Ethics, Issue 11, Vol. 11, PP. 813-829.

Kerin, R. A., Hartley, S. W., and Rudelius, W. (2009). Marketing. New York, NY, McGraw-Hill - Irwin, Chapter 4, p. 105.

Kotler, P., and Keller, K. (2006). Marketing Management (12th edition). New Jersey, Pearson Prentice-Hall, Chapter 22, P. 707.

Kotler. P. (1972). What Consumerism Means for Marketers. Harvard Business Review, Issue 50, PP. 48-57.

May, S.K., Cheney, G., \& Roper, J. (Eds.). (2007). The debate over corporate social responsibility. New York: Oxford Press.

Porter, M. E., and Kramer, M. R. (2006). Strategy and Society: The Link between Competitive Advantage and Corporate Social Responsibility. Harvard Business Review, Vol. 84, Issue 12, PP. 78-92.

Pride, W., and Ferrell, O. C. (2008). Marketing (14th ed.). New York, Houghton Mifflin Co., Chapter 4.

Rivoli, P. (2003). Making a Difference or Making a Statement? Finance Research and Socially Responsible Investment. Business Ethics Quarterly, 13(3), 271-288.

Saha, M., and Darnton, G. (2005). Green Companies or Green Companies: Are Companies Really Green, or Are they Pretending to Be? Business \& Society Review, Vol. 110, Issue 2, PP. 117-157.

Terpstra, V., and David, K. (1991). The Cultural Environment of International Business (third edition). 
Cincinnati: South-Western Publishing, p. 12.

Whang, IL-Chung. Awareness of Social Responsibility by Korean Managers in Marketing Practices. International Studies of Mgt. \& Org., Vol. 28, No. 4, Winter, PP. 19-25.

Windsor, D. (2006). Corporate Social Responsibility: Three Key Approaches. Journal of Management Studies, Vol. 43, January, PP 92-114.

Zikmund, W. G. (2003). Business Research Methods (7th edn). Ohio-USA, Thomson, South-Western, chapter 5. 